KATARZYNA DAJCZAK

Politechnika Koszalińska

\title{
Przemysł stoczniowy w Polsce i na świecie
}

Sektor budowy i naprawy statków (przemysł stoczniowy) różni się od innych przemysłów przetwórczych tym, że został on poddany bardzo wcześnie działaniu procesów globalizacji i nie był objęty programami antydumpingowymi. Funkcjonował on zawsze na wolnym rynku światowym, gdzie stocznie walczyły, i walczą obecnie, o kontrakty zarówno w kraju, jak i za granicą (Opinia uzupetniajaca... 2004).

Celem niniejszego opracowania jest przedstawienie stanu polskiego i światowego przemysłu stoczniowego, ze szczególnym podkreśleniem pozycji konkurencyjnej polskich stoczni na rynku globalnym.

\section{STAN POLSKIEGO PRZEMYSŁU STOCZNIOWEGO}

Znaczenie przemysłu stoczniowego dla gospodarki trudno przecenić. W większości państw uprzemysłowionych lub będących w trakcie procesu industrializacji, przemysł stoczniowy jest uważany za sektor gospodarki szczególnie wrażliwy i strategiczny. Przemysł stoczniowy, oferując produkty pochodne doceniane przez inne sektory, dostarcza ważnych środków transportu dla międzynarodowego obrotu towarowego i przyczynia się w sposób decydujący do obronności i bezpieczeństwa, dostarczając marynarce wojennej okrętów o zaawansowanej technologii (Opinia uzupetniajaca... 2004). Tak jest i w światowej, i w polskiej gospodarce.

Przemysł stoczniowy w Polsce tworzą stocznie budujące statki, stocznie remontowe, centra naukowo-badawcze, ośrodki projektowo-konstrukcyjne i przedsiębiorstwa kooperacyjne specjalizujące się w dostawach wyposażenia okrętowego i usług stoczniowych oraz organizacje koordynujące działalność wymienionych wcześniej jednostek, których wspólnym celem gospodarczym jest produkcja morskich środków transportu (Gomułka 2006). Jest to sektor o dużych możliwościach eksportowych, 90\% produkcji ogółem przeznaczana jest na eksport, trafiając do najbardziej wymagających odbiorców na świecie. Sprzedaż jednostek wyprodukowanych w polskich stoczniach to blisko 3,5\% całego naszego eksportu (Nowak, 2005). Sprzedaż statków i usług remontowych umożliwia krajowym wytwórcom urządzeń i systemów okrętowych nie tylko współpracę z polskimi stoczniami, ale również poszerzenie oferty o eksport bezpośredni dla innych odbiorców zagranicznych. 
Stocznie miały i wciąż mają ogromne znaczenie dla regionalnych rynków pracy. Według danych Związku Pracodawców Forum Okrętowe, stocznie w Gdyni, Gdańsku i Szczecinie pod koniec 2004 roku zatrudniały łącznie 15500 pracowników. W samym tylko 2005 r. Gdańska Stocznia Remontowa S.A. utworzyła 300 nowych miejsc pracy, zdobywając na Pomorzu tytuł „Najlepszego Pracodawcy Roku”. Także w ramach Grupy Stoczni Gdynia prawie 300 osób znalazło zatrudnienie i pracuje w zawodach stoczniowych. Ocenia się, że w całym przemyśle stoczniowym w Polsce, a więc w stoczniach produkcyjnych i remontowych, spółkach stoczniowych grup przemysłowych, firmach kooperujących ze stoczniami oraz wszystkich instytucjach naukowych i badawczych związanych z tym przemysłem pracuje łącznie 80-100 tys. osób. W tej liczbie jest wielu wysokiej klasy specjalistów menedżerów, inżynierów i konstruktorów statków (Landowski 2006). I to właśnie ludzie są najcenniejszym zasobem polskich stoczni, często przeżywających trudności finansowe. Dzięki nim stocznie w Polsce mogą konkurować na globalnym rynku stoczniowym, budując bardzo nowoczesne i wyrafinowane technicznie statki. Specjaliści budownictwa okrętowego, wykształceni w krajowych uczelniach, są chętnie zatrudniani w zagranicznych stoczniach i instytucjach okrętowych, uzyskując tam uznanie i prestiż, a kwalifikowani robotnicy stoczniowi są poszukiwani w przemysłach całej Unii Europejskiej i poza nią. Doświadczenie zdobyte w krajowych stoczniach jest dużym kapitałem dla rozwoju indywidualnych karier zawodowych (Apla 2006)

Wartość zakupów materiałowych w roku 2005 wyniosła 594,6 mln USD i w stosunku do okresu ostatniego kryzysu (rok 2002) wzrosła o ponad 28\%. Niestety - znaczna część tej kwoty (356,8 mln USD) została wytransferowana za granicę ze względu na wzrost importu spowodowanego głównie (Gomułka 2006):

- przystąpieniem Polski do Unii Europejskiej;

- zmianą granic celnych pomiędzy członkami UE;

- wprowadzeniem formalnych barier w realizacji dostaw towarów pochodzących z krajów trzecich;

- zmianą struktury klientów polskich stoczni wywodzących się głównie z krajów Unii Europejskiej.

W 2004 r. polskie stocznie przekazały armatorom 25 statków, o łącznej pojemności 448684 CGT (tzw. skompensowane tony brutto) i wartości 754,7 mln USD. To wielkości znacznie lepsze niż w kryzysowym 2003 r., lecz nadal niższe niż średnie z lat poprzednich. Pomimo trudności ekonomicznych polskich stoczni, utrzymywano wysoki poziom techniczny statków projektowanych i budowanych w Polsce. Na prestiżowej liście „wyróżniających się statków roku 2004" (Significant Ships of The Year) Royal Institution of Naval Architects z Londynu znalazły się dwa statki polskiej budowy: kontenerowiec arktyczny Mary Artica z Gdańskiej Stoczni Remontowej S.A. i statek wielozadaniowy Suomigracht ze Stoczni Szczecińskiej Nowej. Z kolei Stocznia Gdynia S.A. na XII Międzynarodowych Targach Morskich Baltexpo 2004 zdobyła nagrode „Złotej Kotwicy” za najlepszy produkt, jakim został samochodowiec budowany w ramach serii 8168 (Landowski 2006).

Według zestawienia CESA, w 2005 r. polskie stocznie przekazały armatorom na świecie 50 statków (dwa razy więcej niż rok wcześniej) o łącznym tonażu 638500 CGT, co dało nam czwarte miejsce w Europie, za Niemcami, Holandią i Hiszpanią. W 2005 roku w polskich stoczniach zamówiono ogółem 48 nowych statków o łącznej pojemności 545800 CGT, co plasuje nas na piątym miejscu w Europie, za Niemcami, Holandią, Hiszpanią i Rumunią. Cały portfel zamówień wszystkich polskich stoczni, wg stanu na 31 grudnia 2005 r., wynosił 
123 statki o łącznym tonażu $2 \mathrm{mln} 115$ tys. CGT. W Europie wyprzedziła nas tylko Holandia (238 statków) i Niemcy (188 statków) (Landowski 2006).

Sektor ten nie jest jednak pozbawiony problemów i kryzysów. Na początku lat 90. nad większością polskich stoczni wisiało realne widmo bankructwa, wynikające z transformacji gospodarczej, utraty tradycyjnych rynków zbytu oraz niewyjaśnionych płatności od odbiorców z krajów b. ZSRR. Groźbę bankructwa wielu stoczni odsunęły dokonane w nich zmiany własnościowe oraz restrukturyzacje, co miało miejsce głównie w latach 1993-1995. Branża stoczniowa jest niemal w całości sprywatyzowana i znajduje się w rękach polskiego kapitału - firm handlowych, produkcyjnych, banków oraz osób fizycznych. Naszym stoczniom udało się również przeprowadzić postępowania układowe z wierzycielami. Jednocześnie zaczęły wykorzystywać światową koniunkturę na statki, zmieniły profil produkcji i zdobyły nowych klientów (Przemyst stoczniowy 2005). Jednak sytuacja na rynkach światowych zmieniła się przez nieuczciwe działania Korei Południowej. Odbiło się to w sposób znaczący na finansowaniu działalności polskich stoczni, które stały się deficytowe, a banki w związku z tym odmawiały udzielania kredytów na sfinansowanie kolejnych kontraktów.

\section{PRZEMYSŁ STOCZNIOWY W EUROPIE I NA ŚWIECIE}

Na świecie trwa boom na nowe statki i usługi stoczniowe. Specjaliści twierdza, że tak będzie i w najbliższych latach. Wskazują na to statystyki. Systematycznie rośnie bowiem światowy portfel zamówień na nowe statki. Według danych CESA (Community of European Shipyards' Associations), na koniec 2005 roku światowy portfel zamówień na statki wynosił 104,8 mln CGT (łączna pojemność w skompensowanych tonach brutto), czyli $229 \mathrm{mln}$ dwt (łączna nośność), co jest wielkością rekordową. Wzrasta produkcja statków, a co za tym idzie zwiększa się światowa flota handlowa. Według długoterminowych prognoz, w latach 2010-2020 produkcja światowych stoczni wzrośnie ponad 30\%, konsumpcja ropy - o ponad $50 \%$. Podobny wzrost nastąpi w handlu drogą morską. W tej dekadzie potrzebnych będzie o 40\% więcej statków niż jest ich obecnie. Rekordowo zapowiada się najbliższe pięć lat. Część starych statków będzie złomowana, trzeba będzie budować nowe. Złomowane będa głównie masowce i kontenerowce. Obecnie najszybciej wzrasta flota statków przewożących ładunki zjednostkowane, głównie kontenerowców. W 2005 roku kontenerowce stanowiły $27,7 \%$ wszystkich nowo zamówionych statków na świecie - w Europie było to 32,7\% (Landowski 2006)

Europejski przemysł stoczniowy, będąc istotnym elementem gospodarki morskiej ma znaczenie strategiczne dla jednoczącego się kontynentu. Dzieje się tak, ponieważ w regionach nadmorskich mieszka dziś prawie połowa ludności UE i wytwarzana jest blisko połowa europejskiego Produktu Krajowego Brutto (PKB), a obszary morskie pozostające pod jurysdykcją państw członkowskich są większe niż ich powierzchnia lądowa i mogą zwiększyć się jeszcze w przyszłości. Istotny jest również fakt, że Europa jest otoczona przez cztery morza i dwa oceany, a jej linia brzegowa jest siedmiokrotnie dłuższa niż linia brzegowa Stanów Zjednoczonych i czterokrotnie dłuższa niż Rosji. Z powyższego wynika, że ze względu na swoje regiony peryferyjne Unia Europejska posiada największe na świecie obszary morskie. W strategicznych celach na lata 2005-2009 Komisja Europejska zwraca uwagę na szczególną potrzebę określenia wszechstronnej polityki morskiej ukierunkowanej na rozwój prospe- 
rującej gospodarki morskiej i pełnego potencjału działań związanych z morzem, w sposób zapewniający zrównoważoną ochronę środowiska. Polityka ta powinna być wspomagana znakomitymi rezultatami w dziedzinie badań naukowych, technologii oraz innowacyjności (Gomułka 2006).

Pozostaje jednak faktem, że z powodu globalizacji gospodarki budowa statków przenoszona jest sukcesywnie do rejonów, w których można to robić taniej. Na tym polu stocznie europejskie poniosły porażkę. W przypadku standardowych statków transportowych przegrały konkurencję ze stoczniami wschodnioazjatyckimi Japonii, Korei i Chin. Dla tego typu jednostek o możliwościach i kosztach budowy decydują koszty pracy, dostępność wiedzy i możliwości mobilizacji kapitału. Z uwagi na jednostkową produkcję, gabaryty, masy i szczególne wymagania konstrukcyjno-technologiczne, podczas budowy statków w ograniczonym stopniu można wykorzystywać mechanizację i robotyzację produkcji. Dominują wciąż ręczne prace montażowe. To produkcja pracochłonna, więc jednostkowe koszty pracy mają duży wpływ na koszt budowy statków. Gospodarki wschodnioazjatyckie okazały się skuteczniejsze od europejskich także w zakresie umiejętności zapewnienia kapitałów inwestycyjnych dla budowy statków. To wszystko, wsparte azjatycką kulturą pracy, zadecydowało o przewadze konkurencyjnej nad stoczniami europejskimi w budowie statków transportowych (Skrzypiński 2006).

Działania azjatyckich stoczni wpłynęły negatywnie na stocznie Unii Europejskiej. Jak wynika z obserwacji OECD, stoczniowy rynek światowy, szczególnie cykliczny, podlega dużym wahaniom głównie wskutek nadmiernej zdolności produkcyjnej i z powodu różnych form pomocy udzielanej przez państwo. Zaburzenia równowagi między podażą a popytem w tym sektorze były przede wszystkim spowodowane państwowymi inwestycjami strategicznymi w Azji, wywierając negatywny wpływ na środowisko wolnej wymiany handlowej, które charakteryzuje rynek światowy w tym sektorze. Znalazło to odbicie w cenach stosowanych na tym rynku. Wśród państw azjatyckich szczególnie Korea Południowa stosuje praktyki nieuczciwej konkurencji (Opinia uzupetniajaca... 2004), tj.:

- oferowanie cen poniżej kosztów, nie pokrywające nawet kosztu produkcji, z marżami ujemnymi, oscylującymi pomiędzy $20 \%$ a $40 \%$;

- przyznawanie stoczniom nieprzejrzystej pomocy bezpośredniej i pośredniej;

- utrzymywanie w ruchu stoczni będących w stanie bankructwa, nie licząc się ze zobowiązaniami podjętymi przez Koreę w zamian za dostęp do korzystania z pomocy Międzynarodowego Funduszu Walutowego.

W lipcu 2002 roku, wobec narastającej presji konkurencji i apeli przemysłu stoczniowego, które zostały poparte przez Parlament Europejski, Rada Wspólnoty podjęła decyzję dotyczącą sposobu zwalczania nieuczciwej konkurencji na rynku stoczniowym, przyjmując dwutorową politykę: $\mathrm{z}$ jednej strony dała Korei kolejną szansę na zawarcie dwustronnego porozumienia do dnia 30 września 2002 r., z drugiej strony ministrowie uzgodnili, że brak zawarcia takiego porozumienia oznaczać będzie automatycznie odwołanie się do WTO i w ramach przejściowego posunięcia ochronnego - przyznanie stoczniom pomocy bezpośredniej w wysokości do 6\% na budowę maksymalnie trzech typów statków (Opinia uzupetniajaca... 2004). Dwustronne rozmowy z Koreą Południową zakończyły się w październiku 2002 roku, bez żadnych oznak zbliżenia stanowisk, dlatego też Unia Europejska aktywowała mechanizm tzw. ochrony tymczasowej, który zezwala na przyznawanie pomocy bezpośredniej stoczniom. Dzięki staraniom Komisji Europejskiej i projektowi „LeaderSHIP 2015 - Zabezpieczenie przyszłości europejskiego przemysłu budowy i naprawy statków: 
Konkurencyjność poprzez kompetencję" na dalsze funkcjonowanie europejskiego, a także polskiego przemysłu stoczniowego można patrzeć z nadzieją. Inicjatywa pod nazwą „LeaderSHIP 2015” podejmuje istotne elementy Strategii Lizbońskiej i jest zastosowaniem nowego zintegrowanego i złożonego podejścia do przemysłu budowy i naprawy statków. Wieńczy ona wspólny wysiłek wszystkich zainteresowanych stron - przemysłu stoczniowego (CESA), związków zawodowych (EFM) i Unii Europejskiej - jaki włożono w celu zapewnienia przyszłości i konkurencyjności tego europejskiego sektora przemysłowego o znaczeniu strategicznym na dynamicznie rozwijającym się rynku, borykającego się z szeregiem problemów i utrudnień (Opinia uzupetniajaca... 2004). Rada Wspólnoty wydała rozporządzenie 1177/2002 przewidujące możliwość zastosowania dopłaty - w wysokości maksimum 6\% wartości kontraktu - na budowę czterech typów statków: chemikaliowców, kontenerowców, produktowców oraz statków typu LNG. Z tej formy pomocy korzystają stocznie niemieckie, holenderskie, włoskie, francuskie, duńskie i hiszpańskie. Z pomocy skorzysta również Polska na takich samych zasadach, jakie są stosowane w krajach UE, co umożliwi zrównanie szans konkurowania na globalnym rynku dla polskich stoczni. Co prawda dotacje dla Polski obejmują na razie tylko trzy polskie stocznie (Stocznia Szczecińska Nowa, Stocznia Gdynia i Stocznia Gdańska), ale nie jest wykluczona dalsza pomoc także dla innych przedsiębiorstw przemysłu stoczniowego.

Europa buduje więc przyszłość swojego przemysłu stoczniowego koncentrując się na produkcji jednostek o wysokiej specjalizacji. Poziom innowacyjności jest tu wysoki, podobnie rzecz ma się z zaangażowaniem w badania, rozwój wyrobów i metod wytwarzania. Europejscy producenci urządzeń i systemów okrętowych są w swej dziedzinie światowymi liderami. Ponadto stocznie nieustannie się zmieniają. Zmienia się ich rola - tradycyjni niegdyś wytwórcy dziś integrują system, współpracują z setkami dostawców i kooperantów, koordynują ich prace, a kluczowym czynnikiem zapewniającym produktywność, innowacyjność i konkurencyjność sektora stoczniowego Europy są kwalifikacje i umiejętności kadry pracowniczej (Skrzypiński 2006).

Pomyślna przyszłość europejskiego przemysłu stoczniowego zależy między innymi od zmiany pokutujących stereotypów. Przez wiele bowiem lat zwolennicy nieskrępowanego wolnego rynku przedstawiali branżę stoczniową jako schyłkową. Pracę w stoczniach określano mianem 3D - Difficult, Dangerous, Dirty, czyli trudna, niebezpieczna, brudna. Taki obraz skutecznie utrwalany był przez kłopoty organizacyjne i finansowe, z jakimi borykało się wiele stoczni, w tym polskich, a także nierzadkie ich bankructwa i likwidacje (Skrzypiński 2006).

Wydawać się więc mogło, że ta dziedzina wytwórczości nie ma perspektyw. Doświadczenie Unii Europejskiej zmusza jednak do zmiany tych opinii - błędnych i szkodliwych, bowiem gospodarka światowa jest w coraz większym stopniu związana z morzem i od niego zależna. Dzieje się tak, ponieważ transport stanowi krwioobieg gospodarki. W transporcie światowym dominuje przewóz surowców i wyrobów statkami, a transport lotniczy i rurociagowy, w relacjach morskich, jest tylko uzupełnieniem. Statki są tym elementem transportu morskiego, którego nie da się zastąpić i nic nie wskazuje na to, aby w dającej się przewidzieć przyszłości ich rola mogła być ograniczona.

Oprócz funkcji transportowych rozwijają się również inne formy wykorzystania mórz. Poza tradycyjnym rybołówstwem wymienić warto: pozyskiwanie surowców zalegających dna i pod dnem morskim, turystykę morską, a także różne formy zagospodarowania i urbanizacji akwenów przybrzeżnych. Dla statków i innych obiektów pływających nie ma alterna- 
tywy - są i będą budowane, podlegając ciagłemu rozwojowi. Kwalifikowanie budownictwa okrętowego do grupy przemysłów schyłkowych jest więc przesadzone (Bieliński 2006).

A polskie stocznie? Polskie stocznie są w stanie konkurować na światowych rynkach okrętowych, mają dobrą opinię wśród armatorów. Statki budowane w polskich stoczniach charakteryzują się wysoką jakością i są wyróżniane w rankingach światowych prestiżowymi nagrodami (Konsolidacja 2006). Wartość portfela zamówień na statki systematycznie się zwiększa i - co ważne - zaczynają przeważać statki charakteryzujące się złożoną konstrukcją, o dużej wartości dodanej (Dudała 2001).

Ponadto polski przemysł okrętowy jeszcze przed wstąpieniem Polski do UE brał czynny udział w kształtowaniu europejskiego przemysłu okrętowego. Branżowa organizacja pracodawców „Forum Okrętowe” od 1995 roku była (i jest) zarówno członkiem AWES (Association of European Shipbuilders and Shiprepairers), jak i członkiem stowarzyszonym CESA (Community of European Shipyards' Associations) (Lewandowski 2005). Wejście Polski do UE pozwoliło na podniesienie międzynarodowej konkurencyjności przedsiębiorstw gospodarki morskiej, napływ inwestycji zagranicznych, wprowadzanie nowych technologii, unowocześnienie zarządzania w gospodarce morskiej, uatrakcyjnienie oferty towarowej i usługowej, jak i otwarcie nowych rynków zbytu (Gdula 2006).

\section{Literatura}

Apla, 2006, Wiele korzyści, „Dziennik Bałtycki” z 21.03.06.

Bieliński J., 2006, Strategiczne znaczenie przemystu okrętowego dla Unii Europejskiej, [w:] Materiaty z konferencji „Polski przemysł okrętowy - spojrzenie w przyszłość”, Gdańsk.

Dudała J., 2001, Samodzielne polskie stocznie, „Nowy Przemysł” nr 7-8.

Gdula A., 2006, Gospodarka morska - tradycje i perspektywy, www.ebn24.com, stan na 19.05.2006;

Gomułka Z., 2006, Wspótzależność i synergia wspótpracy stoczni i kooperantów, [w:] Materiaty z konferencji „Polski przemyst okrętowy - spojrzenie w przyszłośc”, Gdańsk.

Konsolidacja, 2006, www.mgip.gov.pl, stan na 19.05.06.

Landowski G., 2006, Stocznie to przyszlość, „Nasze Morze” nr 3.

Lewandowski J., 2005, Znaczenie członkowstwa dla przemystu stoczniowego, [w:] Materiały z konferencji „Pierwszy rok w Unii Europejskiej - efekt dla Pomorza”, Sopot.

Nowak E., 2005, Przemyst stoczniowy w Europie, PAI, www.europolforum.pl, stan na 06.05.05.

Opinia uzupetniajaca Komisji Konsultacyjnej ds. Przekształceń w Sektorze Przemysłowym dotycząca „Komunikatu Komisji Europejskiej przeznaczonego dla Rady, Parlamentu Europejskiego, Europejskiego Komitetu Ekonomiczno-Społecznego i dla Komitetu Regionów - Projekt LeaderSHIP 2015", 2004, Bruksela, www.esc.eu.int/ccmi/opinions, stan na 06.05.05.

Przemyst stoczniowy, 2005, www.boss.com.pl, stan na 06.05.05.

Skrzypiński S., 2006, Dajcie stoczniom szansę, „Nasze Morze” nr 3.

\section{The shipbuilding industry in Poland and in the Word}

The world economy is, to a larger and larger degree, connected with the sea and dependent on it, therefore there are no alternatives for ships and other naval objects - they are and will be built. It is definitely untrue that the shipbuilding industry decays. The trade is doing well and can do even better, at least with regards to the macroeconomic situation on the world market which enforces the necessity of scrapping a large part of the senescent freight fleet and imposes new requirements of greater safety of 
navigation or environmental protection. In such a situation, Polish shipyards are able to compete on the world's shipping markets; they enjoy a good reputation among ship-owners. The ships built in Polish shipyards are characterized by high quality and are favoured in the world rankings of high prestige, thus the value of order book for ships systematically increases. 